\title{
PENDAMPINGAN DALAM MENGHADAPI PEMBELAJARAN DI MASA PANDEMI BAGI WARGA DUSUN MACANAN
}

\author{
Nofi Nur Yuhenita1), Yuni Ma'rufatul Majid'1), Afan Rif'at Murat'1), Riski Muliyani'1), \\ Royan Aulia Alfahmi' ${ }^{1}$, M. Zaqi Abdillah ${ }^{2)}$ \\ ${ }^{1) B i m b i n g a n ~ K o n s e l i n g, ~ F K I P, ~ U n i v e r s i t a s ~ M u h a m m a d i y a h ~ M a g e l a n g, ~ M a g e l a n g, ~ J a w a ~ T e n g a h, ~ I n d o n e s i a ~}$ \\ ${ }^{2)}$ Teknik Industri, FT, Universitas Muhammadiyah Magelang, Magelang, Jawa Tengah, Indonesia \\ Corresponding author : Nofi Nur Yuhenita \\ E-mail : nofinury@ummgl.ac.id
}

Diterima 21 Desember 2020, Direvisi 22 Januari 2021, Disetujui 24 Januari 2021

\begin{abstract}
ABSTRAK
Covid-19 memberikan banyak dampak pada manusia, salah satunya pada proses Pendidikan yang dari tatap muka menjadi pembelajaran jarak jauh. Banyak kendala yang dihadapi oleh para orang tua dalam membimbing, mengarahkan terutama mengajari anaknya jika ada kesulitan dalam belajar di rumah. Kegiatan pengabdian masyarakat dilaksanakan di Dusun Macanan berupa pendampingan bimbingan belajar di rumah bagi siswa sekolah dasar Dusun Macanan, Tanjung, Muntilan, Magelang. Kegiatan ini dilakukan untuk menumbuhkan motivasi belajar siswa dan membantu permasalahan yang terjadi pada siswa sekolah dasar. Selain itu juga diberikan sosialisasi kepada orang tua agar lebih maksimal dalam mendampingi anak belajar dari rumah. Kegiatan dilakukan dalam tahap persiapan, pelaksanaan, sosialisasi, dan evaluasi. Evaluasi dilakukan dengan diskusi untuk mengetahui kebermanfaatan kegiatan bagi masyarakat.
\end{abstract}

Kata kunci: pendampingan; belajar dari rumah.

\begin{abstract}
Covid-19 has many impacts on the human being, one of those is in the process of learning from faceto-face learning becomes online learning. There are many problems faced by parents in terms of guide and help their child if there are difficulties in studying at home. Community services activity which implemented in Dusun Mancanan in the form of home tutoring assistance for elementary school students in Dusun Macanan, Tanjung, Muntilan, Magelang. This activity is aimed for motivate elementary school students and helping their study problems. On the other hand, also gives socialization for the parents to give maximum result to guide their children to study at home. This event is done in the preparation stage, implementation, socialization, and evaluation. The evaluation is done by discussion to know about usefulness event for the society
\end{abstract}

Keywords: tutoring; study from home.

\section{PENDAHULUAN}

Saat ini covid-19 menjadi musuh besar bagi manusia, akibatnya, banyak kebijakan baru yang menciptakan kebiasaan baru pula. Adanya wabah tersebut yang membuat ancaman bagi seluruh dunia tentu membuat polemik global. Satu diantaranya adalah pendidikan, pendidikan adalah aspek yang berfungsi untuk meningkatkan sumber daya manusia (Wahyuningsih S dan Abbas E. W. \& Mutiani M, 2020).

Pemerintah mengeluarkan berbagai kebijakan sebagai upaya untuk menekan penularan COVID-19 ini. Seperti kebijakan pemerintah untuk melakukan jaga jarak satu sama lain, sektor pendidikan melaksanakan kebijakan work from home atau kegiatan yang biasanya dilakukan di luar rumah akan dilakukan di rumah saja. Dalam proses pendidikan pun, kegiatan pembelajaran yang mulanya dilakukan dengan tatap muka, diubah menjadi pembelajaran jarak jauh atau pembelajaran secara daring. Diberlakukannya pembelajaran jarak jauh tentu menimbulkan dampak pada sektor pendidikan yang telah lama digunakan, juga berdampak pada keefektifan belajar pada peserta didik.

Banyak kendala yang dihadapi oleh para orang tua dalam membimbing, mengarahkan terutama mengajari anaknya jika ada kesulitan dalam belajar di rumah. Banyak orang tua yang mengeluh karena belum optimal dalam membimbing dan mengarahkan apalagi mengajari anak-anaknya dalam belajar di rumah. Hal tersebut dikarenakan sebagian besar orang tuanya bermata pencaharian 
sebagai petani dan mereka harus bekerja ke sawah. Sehingga mereka memiliki waktu yang sedikit sekali untuk mendampingi anaknya belajar. Sebagian orang tua yang mampu, mereka akan mengikutkan anak nya dalam lembaga bimbingan belajar untuk mengatasi masalah belajar yang anak mereka alami. Namun, bagi orang tua yang kurang mampu mereka tidak bisa berbuat banyak untuk membantu mengatasi masalah kesulitam belajar anaknya.

Kesulitan belajar yang dialami seorang siswa akan membuat mereka menjadi malas belajar dan menganggap pelajaran itu sulit dan tidak penting untuk dipelajari. Motivasi belajar anak dapat menurun karena kurang bimbingan dan arahan orang tua saat proses belajar di rumah. Perlu adanya bantuan pendampingan bimbingan belajar di rumah bagi siswa sekolah dasar untuk menumbuhkan motivasi belajar siswa dan membantu kesulitan yang ada pada siswa sekolah dasar.

Berdasarkan pengamatan dan wawancara yang dilakukan kepada kepala dusun Macanan, beberapa orang tua kadang mengeluh karena tidak sempat untuk melakukan pendampingan belajar pada anaknya. Dari paparan di atas, maka kelompok kami ingin melaksanakan kegiatan pengabdian pendampingan bimbingan belajar di rumah bagi siswa sekolah dasar Dusun Macanan, Tanjung, Muntilan, Magelang untuk menumbuhkan motivasi belajar siswa dan membantu permasalahan-permasalahan yang terjadi pada siswa sekolah dasar.

Pendampingan terhadap anak juga perlu dilakukan dalam meningkatkan tingkat spiritual dan perilaku islami anak melalui kegiatan di TPQ. Salah satu cara untuk mewujudkan hal tersebut melalui pembelajaran baca tulis alquran, pelatihan beribadah, dll. Oleh karena itu selain akan melakukan pendampingan dalam pembelajaran jarak jauh atau daring, penulis juga akan melakukan pendampingan dalam pembelajaran di TPQ. Kegiatan ini bertujuan untuk membantu orang tua agar lebih telaten dan bijak dalam mendampingi anak belajar di rumah, selain itu juga membantu anak agar tetap fokus dan dapat belajar sebagaimana mestinya meskipun pembelajaran sekolah dilaksanakan secara daring.

\section{METODE}

Kegiatan pengabdian masyarakat dilaksanakan di Dusun Macanan berupa pendampingan bimbingan belajar di rumah bagi siswa sekolah dasar Dusun Macanan, Tanjung, Muntilan, Magelang. Kegiatan ini dilakukan untuk menumbuhkan motivasi belajar siswa dan membantu permasalahan yang terjadi pada siswa sekolah dasar. Siswa yang mengikuti dalam proses belajar dari Paud sampai SD tingkat akhir yang berjumlah 35 anak. Selanjutnya wali murid/siswa mengikuti kegiatan sosialisasi dalam hal mendampingi anak belajar di rumah.

Kegiatan pengabdian ini dilakukan dalam beberapa tahap, yaitu tahap persiapan, pelaksanaan, dan evaluasi.

1. Tahap Persiapan

Tahap persiapan dimulai dengan mengurus surat izin kepada Kepala Desa Tanjung dan surat tugas untuk melaksanakan kegiatan pengabdian kepada masyarakat. Dalam kegiatan persiapan juga dilakukan koordinasi tim terkait kegiatan pengabdian.

\section{Tahap Pelaksanaan}

Tahap berikutnya adalah pelaksanaan, kegiatan pengabdian kepada masyarakat ini dilaksanakan pada bulan Oktober 2020 di Rumah belajar. Pendampingan belajar diberikan full selama 70 jam dengan dibagi beberapa kelompok kecil dan tentor menghandle anak atau siswa. Teknik pelaksanaan kegiatan pendampingan belajar ini dilakukan dengan memberikan penyampaian materi dan mendampingi anak mengerjakan tugas belajar dari sekolah. Pelaksanaan pendampingan belajar dilakukan dengan menggunakan metode langsung/ekspositori.

\section{Tahap Sosialisai}

Kegiatan pendampingan yang dilakukan selanjutnya adalah sosialisasi atau parenting yang diberikan pada orang tua atau wali murid terkait bagaimana mendampingi anak dalam menjalani kegiatan belajar dari rumah. Kegiatan ini diharapkan agar orang tua dapat melakukan pendampingan belajar pada anak-anak secara mandiri.

4. Tahap Evaluasi

Tahap kegiatan yang berikutnya adalah evaluasi. Kegiatan evaluasi dilakukan untuk mengetahui sejauh mana kegiatan bermanfaat untuk masayarakat dusun Macanan. Kendalakendala yang dihadapi anak atau siswa saat menjalani belajar dari rumah diungkapkan dan dibahas pada saat kegiatan pendampingan belajar berlangsung.

\section{HASIL DAN PEMBAHASAN}

Pandemi Covid-19 menjadikan segala bentuk kegiatan yang biasanya dilaksanakan di sekolah mengalami pergeseran, yaitu dilaksanakan secara daring. (Sumarno, 2020) menyatakan bahwa kegiatan esensial yang harusnya dilakukan di sekolah berubah dilakukan di rumah siswa masing, dan kebanyakan proses pembelajaran yang 
dilakukan antara guru dengan murid ini dilaksanakan dengan keadaan seadanya tanpa persiapan lebih matang.

Secara garis besar pembelajaran secara daring sebenarnya tidaklah hal yang sulit dilakukan dalam era yang modern saat ini, dengan adanya kemajuan teknologi dan informasi yang cepat. Hampir semua tenaga pendidik dan peserta didik memiliki telepon pintar (smartphone), kemudian dengan banyaknya pilihan kemajuan forum diskusi berbasis daring atau aplikasi pembelajaran yang bisa digunakan. Seperti aplikasi zoom, googlemeet, google classroom, dan lain-lain. Pengoprasikannya tidak lah sulit sebab hampir sama saja dengan aplikasi yang umumnya kita gunakan keseharian.

Dikutip dari (Syaharuddin S, 2020) peran media itu sebagai transfer of knowledge, kelemahan teknologi yaitu tidak memiliki rasa, bahasa, dan karakter. Oleh karena itu, peran ini harus menjadi milik seorang tenaga pendidik yang tidak hanya menjalankan fungsi mentransferkan ilmu pengetahuan tetapi juga mampu membentuk sikap dan perilaku sebagai tugas tenaga pendidik. Seperti pendapat (Nuriansyah, 2020) bahwa media pada pembelajaran daring digunakan sebagai alat untuk meningkatkan efesiensi dan efektivitas pembelajaran. Media dipergunakan untuk mencapai tujuan seperti membuat jelas pesan secara visual sehingga tidak terlalu verbal. Media juga menjadi jembatan untuk mengatasi keterbatasan ruang, waktu dan lima indra, mempercepat proses belajar dan mengajar, menimbulkan semangat dalam belajar, memberikan kesempatan bagi perserta didik untuk berinteraksi langsung dengan lingkungan mereka dan kenyataan di lapangan, serta memberikan kesempatan kepada peserta didik untuk belajar mandiri berdasarkan kemampuan dan minat yang dimiliki.

Namun, pada beberapa pihak banyak sekali problematika yang dialami siswa dalam proses pembelajaran jarak jauh saat ini, sehingga bisa menimbulkan konsekuensi yang luas. Belajar secara daring (online) mensyaratkan sarana dan prasarana yang memadai, baik bagi para guru maupun siswa, namun kenyataannya tidak semua siswa memiliki akses yang memadai.

Banyak warga masyarakat, khususnya dari warga kurang mampu, mengalami kesulitan menyediakan sarana dan prasarana tersebut bagi anak-anak mereka. Selain itu, banyak daerah terpencil yang tidak terjangkau jaringan internet sehingga menyulitkan anakanak belajar. Selain itu untuk siswa sekolah dasar sejatinya mereka sangat membutuhkan pendampingan dalam proses belajar. Hal ini sejalan dengan (Basar et al., 2021) yang dalam studinya menemukan berbagai permasalahan pada siswa saat mengikuti pembelajaran jarak jauh, yaitu siswa yang kurang mampu memahami isi materi yang dipaparkan lewat media online oleh guru, jaringan internet yang terkadang terganggu, kurangnya penggunaan media pembelajaran secara online sehingga beberapa materi pelajaran yang membutuhkan alat dan/atau media pembelajaran tertentu tidak dapat tersampaikan secara maksimal.

Di dalam sekolah mereka mempunyai guru yang bertugas sebagai pendamping dan fasilitator. Namun, di masa pandemi siswa melakukan belajar secara daring dari rumah nya masing-masing, sehingga orang tua lah yang bertugas sebagai pendamping dan fasilitator. Jadi, saat ini orang tua lah yang mempunyai peran penting dalam pembelajaran anak di rumah.

Program pengabdian ini tidak lepas dari salah satu program Universitas Muhammadiyah Magelang. Tujuan dari Program Pengabdian Masyarakat Terpadu (PPMT) ini untuk meningkatan mutu dan relevansi pembelajaran yang berorientasi pada pembentukan karakter dalam pembelajaran secara daring. Kegiatan pengabdian ini dimulai dengan koordinasi dengan tim pelaksana dan Universitas. Setelah mendapatkan ijin tim pelaksana berkoordinasi dengan perangkat Desa Tanjung. Hasil dari diskusi (FGD) kemudian menentukan permasalahan yang dihadapi.

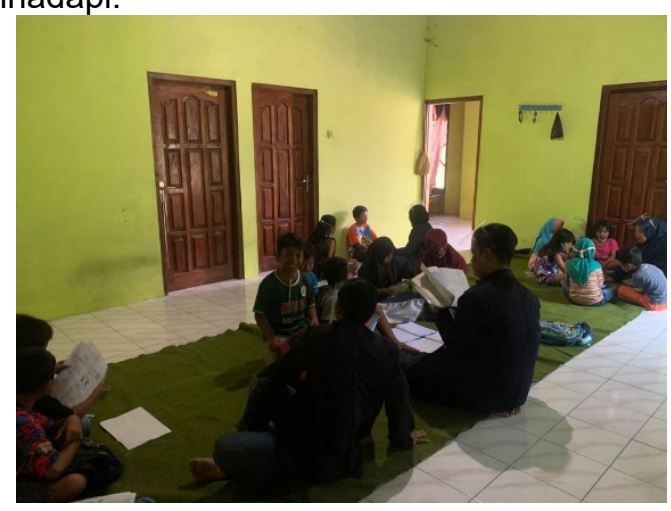

Gambar 1. Pendampingan Belajar Pada Siswa

Kegiatan sosialisasi kepada kelompok sasaran, kelompok sasaran ini anak Sekolah Dasar yang sangat membutuhkan dalam pendampingan belajar secara daring pada hari Senin, 24 Agustus 2020 di Desa Tanjung. Dalam sosialisasi dihadiri oleh bapak Kadus Dusun Macanan Desa Tanjung. Dalam sosialisasi tim pelaksana menyampaikan tentang tujuan kegiatan PPMT, jadwal kegiatan, kegiatan yang akan dilakukan dan kontribusi 
masyarakat terhadap kegiatan PPMT ini pimpinan TPQ yang selanjutnya disebut mitra.

Kegiatan sosialisasi dengan ketua remaja Dusun Macanan membahas tentang perencanaan kegiatan. Kegiatan sosialisasi dengan pimpinan TPQ selaku mitra dalam pengabdian masyarakat dalam pendampingan belajar dan mengumumkan kepada anak-anak Dusun Macanan Desa Tanjung dari Sekolah Dasar untuk proses pelaksanaan pendampingan belajar.

Kegiatan pendampingan belajar dari rumah bertujuan kegiatan untuk menumbuhkan motivasi belajar siswa dan membantu permasalahan-permasalahan yang terjadi pada siswa sekolah dasar. Kegiatan pendampingan belajar yang ditunjukkan gambar 1 ini mulai dilaksanakan pada tanggal 14 Oktober 2020 di Dusun Macanan Desa Tanjung. Tim pelaksana melakukan pendampingan setiap hari senin sampai kamis. Tim juga memberikan edukasi tentang bahaya covid-19 dengan menyuruh anak didik mengambar virus dengan imajinasi mereka.

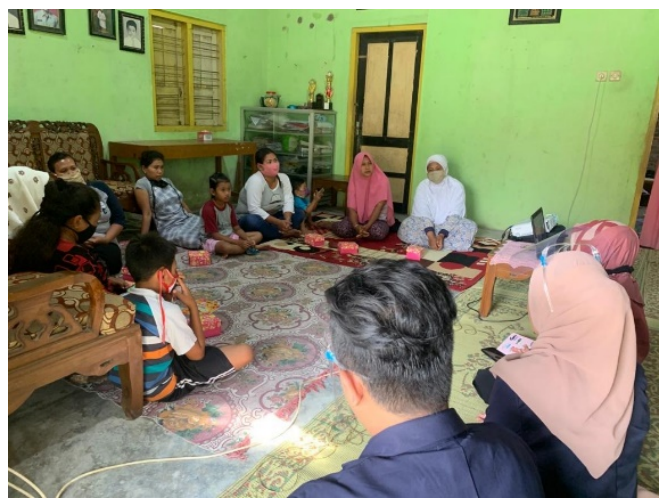

Gambar 2. Kegiatan Sosialisasi

Pendampingan Belajar pada Orang Tua

Kegiatan pendampingan belajar dilakukan karena melihat bahwa selama pembelajaran daring, kebanyakan siswa mengalami hambatan. Seperti yang dikemukakan (Handayani et al., 2020) bahwa pembelajaran daring membuat siswa bosan karena tidak dapat bertemu dengan temanteman. Belajar bersama teman-teman lebih menyenangkan daripada belajar sendirian di rumah. Begitu juga guru, dalam pembelajaran daring, guru mempunyai keterbatasan ruang dalam menyampaikan dan menjelaskan materi. Kondisi ini menjadikan siswa merasa tidak paham dengan materi yang disampaikan. Meskipun ada orang tua di rumah di rumah, namun tidak semua siswa dapat dibimbing oleh orang tuanya setiap waktu dalam belajar, salah satunya karena orang tua yang sibuk bekerja.

Kegiatan berikutnya adalah sosialisasi dan parenting kepada orang tua/wali murid yang dilaksanakan pada hari sabtu 24 Oktober 2020 seperti ditunjukkan gambar 2. Materi yang disampaikan dalam sosialisas berupa bagaimana cara dan tips mendampingi anak belajar di rumah secara daring. Kegiatan berikutnya adalah lomba untuk anak-anak. Kegiatan parenting ini dilakukan sejalan dengan yang disampaikan (Handayani et al., 2020) bahwa siswa yang dibantu oleh orang tuanya selama masa pembelajaran daring juga memiliki hambatannya sendiri, misalnya keterbatasan orang tua siswa terkait pengetahuan pada materi yang sedang diajarkan. Hal ini akan mempengaruhi semangat dan hasil belajar siswa.

Kegiatan lomba ini untuk menigkatkan rasa sportifitas anak didik agar memiliki pribadi yang semangat tinggi, dan motivasi untuk menjadi yang terbaik. Kegiatan ini berupa mewarnai, mengambar, membuat poster, dan membaut kerajinan menganyam. Anak didik sangatlah antusis dari kegiatan lomba. Kegiatan ini bertujuan untuk meningkatkan sportifitas dan keakraban anak-anak. Kegiatan lomba juga dilakukan sebagai penutup rangkaian kegiatan pengabdian.

\section{SIMPULAN DAN SARAN}

Kegiatan yang diikuti oleh masyarakat Dusun Macanan Desa Tanjung Kecamatan Muntilan ini berjalan dengan baik. Para peserta atau anak didik sangatlah antusias mengikuti dari awal perkenalan, pendampingan belajar, sosialisasi, dan pamit. Kegiatan ini pendampingan belajar pembentukan karakter dalam pembelajaran secara daring dan dapat menyalurkan informasi kepada masyarakat terutama yang memilki anak Sekolah Dasar dalam pendampingan belajar dirumah.

\section{UCAPAN TERIMAKASIH}

Tim mengucapkan terima kasih kepada LPPM Universitas Muhammadiyah Magaelang yang telah memfasilitasi pembiayaan dan terlaksananya kegiatan PPMT ini.

\section{DAFTAR RUJUKAN}

Basar, A. M., Islam, P. A., Nurul, S., Cikarang, F., \& Bekasi, B. (2021). Problematika Pembelajaran Jarak Jauh Pada Masa Pandemi Covid-19 ( Studi Kasus di SMPIT Nurul Fajri - Cikarang Barat Bekasi ). Edunesia: Jurnal Ilmiah Pendidikan, 2(1), 208-218.

Handayani, T., Khasanah, H. N., \& Yoshinta, R. (2020). Pendampingan Belajar Di Rumah Bagi Siswa Sekolah Dasar Terdampak Covid-19. ABDIPRAJA (Jurnal Pengabdian Kepada $\begin{array}{lll}\text { Masyarakat), } & 107 \text { (1), }\end{array}$ 
https://doi.org/10.31002/abdipraja.v1i1. 3209

Nuriansyah, F. (2020). Efektifitas Penggunaan Media Online Dalam Meningkatkan Hasil Belajar Pada Mahasiswa Pendidikan Ekonomi Saat Awal Pandemi Covid-19. Jurnal Pendididikan Ekonomi Indonesia, 1(2), 61-65. https://ejournal.upi.edu/index.php/JPEI /article/view/28346

Sumarno. (2020). Adaptasi Sekolah Dalam Mengimplementasikan Pembelajaran Jarak Jauh Pada Masa Pandemi Covid19 (Studi Kasus Smp Muhammadiyah Karanggeneng Kabupaten Lamongan). Jurnal Tarbiyah \& IImu Keguruan (JTIK) Borneo, I(2), 149-162.

Syaharuddin S. (2020). Menimbang Peran Teknologi dan Guru dalam Pembelajaran di Era COVID-19. Universitas Lambung Mangkurat. http://eprints.ulm.ac.id/9148/1/2.

Menimbang Peran Teknologi dan Guru dalam Pembelajaran di Era COVID19.pdf

Wahyuningsih S dan Abbas E. W. \& Mutiani M. (2020). Implementation of Leadership Value of Rudy Resnawan as a Leaning Resources on Social Studies. The Innovation of Social Studies Journal, 1(2), 169-177. 